\title{
Dijital Çağın Hedonist Çalışanları: Dijital Göçebeler
}

\section{Dr. Aysun Kaya Deniz ${ }^{*}$}

Gelis tarihi: 02.07.2019

Kabul tarihi: 07.08.2019

\section{Atıf bilgisi:}

IBAD Sosyal Bilimler Dergisi

Sayı: 5

Sayfa: 101-113

Yıl: 2019

Dönem: Güz

This article was checked by Turnitin. Similarity Index 4\%

1 İstanbul Gelişim Üniversitesi, Türkiye, akaya@gelisim.edu.tr

ORCID ID 0000-0002-3592-0996

* Sorumlu yazar
ÖZ

İçerisinde yaşadığımız dönem dijitalleşmenin gündelik hayatımızın her anında hâkim olduğu bir dönemdir. Postmodernizmin etkisinin altında olan günümüz toplumunda bireyler, haz odaklı bir yaşam sürmekte ve yaşantılarını bu doğrultuda șekillendirmektedir. Sürekli yeni ve farklı olanın peşinde koşarak mutluluğu arayan hedonist bireylerin dijitalleşme ile birlikte çalışma hayatlarında da değişiklikler yaşanmaya başlamıştır. Anı yaşamaya odaklı hedonist bireyler dijitalleşmenin de sağladığı olanaklarla birlikte artık çalışma hayatlarının da merkezine haz kavramını koyarak kendilerine konforlu ve eğlenceli çalışma alanları arayışına girmiş ve ortaya yeni bir kavram çımıștır: Dijital göçebeler. Dijital göçebeler için bilgisayarın, internetin ve aynı zamanda da keyif alabilecekleri ortamların olduğu her yer çalışma ortamıdır. Tek bir mekâna bağlı kalmaksızın keyif alabilecekleri ortamlarda çalışarak kendi özgürlüklerini yaratan dijital göçebeler bu çalışmanın ana kavramıdır. Rutin olanın dışına çıkarak, çalı̧̧ma ortamlarını keyifli vakit geçirerek haz alabilecekleri ortamlara dönüştüren dijital göçebelerin sayılarının dijitalleşme alanında yaşanan gelişmelere bağlı olarak gün geçtikçe artmaktadır. Bu çalışmada, literatüre yeni giren "dijital göçebeler" kavramı dijitalleșme, hedonizm ve haz odaklı yaşayan hedonist bireyler çerçevesinde ele alınmıştır

Anahtar Kelimeler: Hedonizm, Hedonist Birey, Dijitalleşme, Dijital Göçebeler 


\section{Hedonist Workers of the Digital Age: Digital Nomads}

\section{Dr. Aysun Kaya Deniz ${ }^{1^{*}}$}

First received: 02.07.2019

Accepted: 07.08.2019

\section{Citation:}

IBAD Journal of Social Sciences

Issue: $5 \quad$ Pages: 101-113

Year: 2019 Session: Fall

This article was checked by Turnitin. Similarity Index 4\%

1 İstanbul Gelisim University, Turkey, akaya@gelisim.edu.tr

ORCID ID 0000-0002-3592-0996

* Corresponding Author

\begin{abstract}
Today, digitalization dominates every moment of our daily lives. In today's society, which is under the influence of postmodernism, people live and shape their lives according to the pleasure. Along with the digitalization, many changes have started to take place in the hedonist people's working lives who seek happiness by constantly pursuing the new and different things. Due to the opportunities provided by digitalization, the hedonist people who give the importance to live the moment, put the concept of the pleasure at the center of their working lives and started to search the comfortable and enjoyable working places. A new concept has emerged: Digital Nomads. If a place where the digital nomads can spend enjoyable moments has an internet connection and a laptop, this place can become their working places. The main concept of this study is the digital nomads who can create their own freedom working as a freelancer in the places that they can spend enjoyable moments. The number of digital nomads is increasing day by day due to the developments in the field of digitalization. In this study, the concept of "digital nomads", which has recently taken part in the literature, has been discussed within the framework of the digitalization, hedonism and hedonist person.
\end{abstract}

Keywords: Hedonism, Hedonist Person, Digitalization, Digital Nomads 


\section{GİRIŞ}

Günümüz toplumuna postmodernizmin ve teknolojik gelişmelerin etkileri hâkim olmaktadır. Bireyler, toplumla birlikte bir bütün halinde yaşamak yerine daha bireysel bir yaşam sürmeyi tercih etmekte ve bireyselleşen bireyler de gündelik hayatlarını dijital ortamlar üzerinden var etmektedir. Bireylerin iletişim süreçlerinden tüketim alışkanlıklarına kadar gündelik hayatlarında yer alan tüm süreçler artık dijital ortamlar üzerinden var olmaya başlamıştır. Küreselleşmenin de getirdikleriyle birlikte bireylerin iş hayatlarında da sınırlar ortadan kalkmış, zaman ve mekâna bağlı kalmaksızın bireyler artık küresel dünyanın küresel işçileri haline gelmiştir. Dijital ortamların gelişmesi ve temelinde etkileşimi barındıran teknolojik yeniliklerin internet ortamında baş göstermesiyle birlikte bireylere uzaktan çalışma olanakları da sağlamaya başlamıştır. Evler ofislere dönüşmeye başlamış ve çalışma saatlerinde de esneklik ortaya çıkmıştır. Yaşanan bu gelişmelere ek olarak, günümüz bireyinin hayata olan bakış açısında da değişiklikler söz konusu olmaya başlamıştır. Tüketmek için üreten, çalıştığını güzel vakit geçirmeye ve eğlenmeye harcayan, tükettikleriyle toplumda var olmaya çalışan ve anlık hazların peşinde koşarak mutluluğu arayan hedonist bireylerin doğuşu söz konusudur. Dijitalleşme ile birlikte yaşanan gelişmeler, keyif almak, mutlu olmak, anı yaşamak gibi durumlardan beslenen hedonist bireylerin çalışma hayatlarında da özgürleştirici yeni bir kapı açmıştır: Dijital göçebelik.

Dijital göçebelik kavramı, en temel hali ile bireylerin bir yandan seyahat edip güzel vakit geçirirken, bir yandan da dijital ortamlar üzerinden çalışarak para kazanmalarıdır. Bir başka deyişle, bireyler dünyayı gezerek hem seyahat edip farklı yerler keşfetmekte, hem de para kazanmaya devam etmektedir. Mekândan bağımsız evden ya da uzaktan çalışanlar ile dijital göçebeler birbirlerinden ayrı kavramlardır. Dijital göçebeler çalışacakları mekânların eğlenebilecekleri, hobilerini gerçekleştirebilecekleri, keyif alabilecekleri ve anı en iyi şekilde yaşayarak hazza erişebilecekleri yerler olmasına dikkat etmektedir. İşe göre ülke ve mekân seçiminden ziyade, seyahatlerine yön verecek keyif alabilecekleri ama aynı zamanda da geçimin kolay ve internet erişiminin iyi olduğu yerleri seçmektedir. Anı yaşayan, keyif almak için seyahat eden ama aynı zamanda da çalışma hayatına devam eden dijital göçebelerin yaşam tercihlerinin temelinde haz kavramı yer almaktadır. Haz odaklı bir yaşam şekline sahip olan dijital göçebelerin mekândan bağımsız, dünyanın herhangi bir yerinde çalışma ortamına sahip olmasının altında dijital alanda yaşanan teknolojik gelişmeler yatmaktadır.

Haz odaklı yaşam süren hedonist bireyler ve dijital ortamlarda yaşanan teknolojik yenilikler, dijital göçebelik kavramının daha iyi bir şekilde anlaşılabilmesi için ele alınması gereken temel kavramlardır. $\mathrm{Bu}$ çalışmanın ilk bölümünde hedonizm ve hedonist birey kavramları incelenecek, ikinci bölümünde dijitalleşme ve dijitalleşme ile birlikte yaşanan gelişmeler ele alınacak ve son olarak da dijital göçebeler kavramı hedonist birey ve dijitalleşme kavramı çerçevesinde değerlendirilecektir.

\section{HEDONIZM VE HEDONIST BİREY KAVRAMLARINA GENEL BİR BAKIŞ}

Tarihten günümüze insanoğlu nasıl mutlu olacağı ve nasıl mutlu bir yaşam sürdürebileceği sorularına cevap aramıştır. Bireylerin içerisinde yaşadığı toplum ve toplum düzeni mutlu bir yaşamın şekillenmesinde etkili olmuştur. İlkel dönemlerde üreterek, ürettiğini bölüşerek ve paylaşarak mutlu olan insanların yerini günümüzde sahip olma arzusu ile sürekli yeni olanın peşinde koşan bireyler almıştır. (Fromm, 2003, s.25) Postmodernizmin hâkim sürdügü günümüz toplumunda bireyler, bitiş çizgisi olmayan bir yarışın içerisinde sürekli yeni olanın peşinde koşmaktadır. (Bauman, 2011, s.110). Sürekli yeni olanın peşinden koşmak ve yeni olana erişmek bireylerde anlık hazların yaşanmasına yol açmakta ve bu bireyler toplumumuzda hedonist birey olarak yer almaktadır. Hedonizm kavramı farklı disiplinlerde farklı bakış açıları ile alınmış olsa da, hedonizm düşüncesi ilk olarak Antik Yunan kültüründe ortaya çıkmıştır. İlk olarak Sokrates' in öğrencileri tarafindan ele alınan kavram en genel hali ile "yaşamın anlamının, hazzın yaşamın temelinde bulunduğunu kabul eden felsefi bir görüş" olarak açıklanmıştır. Hedonizm bağlamında zevk kavramı, bireylerin yaşamlarına yön vermektedir. (Fromm, 2014, s.201) Hedonizm kavramı "mutlu yaşamın ne olduğu" sorusuna cevap arayan Aristippos tarafından ortaya çıkarılmış ve Epikuros tarafindan da temsil edilmiştir. Aristippos'a göre mutlu bir hayat sürebilmenin altında az acı ve çok haz yer almakta ve az acının ve hazzın fazla olduğu mutlu bir yaşam da "anlık" hazzı yaşayabilmek ile ortaya çıkmaktadır. Bireylerin "anlık" hazlar ile mutlu olabileceği düşüncesinde olan Aristippos, her daim eğlence peşinde olan, gelecek kaygısı çekmeyen, 
anın kıymetini bilen ve neşesini kaybetmeyen ama bir yandan da kendisini kontrol edebilen bireylerin mutlu bir yaşam sürdüğü düşüncesindedir. (Akarsu, 1998, s.64). Bireylerin en üst seviyede haz alarak yaşamasını ama bunu gerçekleştirirken de ölçünün kaçırılmaması gerektiğinin altını çizen Aristippos, aklın duyular tarafından kışkırtılan ve sonu gelmeyen istekleri kontrol altına alması ile erdem ve hazzın ölçülü olabileceğini söylemektedir. Gerçek haz sürekli olandır ve bireyler bilgelik ile gerçek hazza ulaşabilmektedirler. (Hancerlioğlu, 2000, s. 75). Aristippos bireysellik kavramına daha çok önem vermiştir bu yüzden onun için gerçek haz bireysel olan hazdır.

Hedonizm kavramının bir diğer temsilcisi olan Epikuros, mutluluğun ölçülü ve geçici değerlerden uzak bir yaşamla mümkün olabileceği üzerinde durmuştur. Epikuros'a göre aldatıcı ve geçici değerlerden uzak durmayan bir birey, sürekli olarak daha fazlasina sahip olmak isteyecek ve isteklerinin sonunun gelmeyeceğini fark ettiği zaman da mutsuzluğa sürüklenecektir. Bir başka deyişle, Epikuros'a göre aşırılık her zaman eleme neden olmaktadır. Epikuros'un ölçülü bir yaşamdan kastı da aslında bireylerin hazzı elde etmeye çalışırken, elemden mantıklı bir şekilde kaçması gerektiğidir. (Aster, 2005, s. 296). Para ve malın bireylere mutluluk getirmeyeceği düşüncesinde olan Epikuros, bireylerin pahalı yiyeceklerin ve içeceklerin yer aldığı ziyafet ortamlarından ve bu ortamlardaki sevgi zevklerinden kendilerini soyutlayarak, makul ihtiyaçlar ile sade ve basit bir yaşam sürerek mutlu olabileceklerinin görüşündedir. (Epiküros, 2014, s.12). Dostluk kavramının da bireylerin mutluluğa erişmesinde önemli bir yere sahip olduğunun belirten Epikuros, "bir şey yiyip içmeden önce, ne yiyip içeceğiniz değil, kiminle yiyip içeceğinizi düşünün; çünkü yanında arkadaşı olmaksızın yemek yemek ancak bir aslana ya da kurda ait bir durumdur" ifadesiyle de dostluk kavramının bireylerin mutluluğunda ne kadar etkili olduğunun altını çizmektedir. (Epiküros, 2014, s.74). Haz kavramı bireylerin yaşamlarında olması gerektiği kadar olmalıdır. Aldatıcı ve geçici hazlar doğrultusunda yaşamlarına şekil veren bireyler uç noktalarda bir yaşam sürmeye başlarlar. Bu uç noktalardaki yaşamda uç noktalardan derinlere bir düşüş söz konusudur. Aldatıcı ve geçici hazlarla uç noktalarda yaşayan bireylerin yaşamını giderek etkisi artan durumların tatmin hissi de giderek azalır ve bu durum sonucunda da bireyler doyuma ulaşamadıkları için kısır bir döngü içerisinde hapsolmuş bir şekilde yaşamlarını sürdürürler. (Vernon, 2010, s. 35).

Antik dönemde Aristippos ve Epikuros tarafindan ele alınan hedonizm kavramı, haz ve mutluluk kavramlarıyla birlikte ele alınarak, bu alanda düşüncelerin geliştirilmesi sonucunda modern dönemde faydacılık teorisi ortaya çıkmışıı. Antik dönemlerde Aristippos ve Epikuros mutluluğu bireyci mutluluk olarak ele almıştır. Modern dönemde Jeremy Bentham ve Stuart Mill'un faydacı bakış açısı ile birlikte bireyci mutluluk yerini "her şey insan için" düşüncesi çerçevesinde insan mutluluğuna odaklanan faydac1 teoriye bırakmıştır. Faydacı teori doğrultusunda, bireyler haz ve mutluluklarını elde edebilmek için çaba sarf etmelidir. Bu teori doğrultusunda, bireyler için faydalı olan unsurlar iyi, fayda sağlamayanlar ise kötü olarak ele alınmaktadır. Teoriye göre mutluluk, bireyci olmaktan ziyade; bireylerin birlikte yaşadığı kişiler ile elde edilmektedir. Faydacı teori düşünürlerinden Jeremy Bentham ve Stuart Mill, "en büyük sayıdaki insanın en büyük mutluluğu" düşüncesinden doğrultusunda en büyük hazzın, fazla sayıdaki insana en fazla seviyede fayda veren haz olduğunu söylemektedirler. Bu doğrultuda, kişiler bireysel haz yerine, yaşantısındaki diğer kişilerin de mutluluğunu önemsemelidir. (Möngü, 2015, s. 29).

Eleştirel kuram doğrultusunda hedonizm kavramı ele alındığında, Marcuse çalışmalarını gerçekleştirdiği dönemin şartları doğrultusunda yüksek mutluluğa erişilip bu mutluluğun yaşanabileceği düşüncesini reddetmiştir. Bu dönemlerde hedonizm felsefesinde yer alan mutluluk kavramı; tüketim eylemi ile bir tutulmuş ve çalışmadan uzak, bir boş zaman kavramına indirgenmiştir. (Jay, 2006, s.93). Marcuse'nin bakış açısı doğrultusunda, hayatın merkezine çalışma eylemini koyan bireylerin, kendi mutluluklarının ne ve nerede olduğunu anlayabilmeleri çok zordur. Adorno ise, bireylerin kapitalist sisteme hizmet eden kültür endüstrisinin vaat ettikleri ile aldatıldığ 1 düşüncesindedir. Adorno'ya göre, kültür endüstrisi tarafindan bireylere sunulan metalar aracılığı ile bireylere vaat edilen haz, "vadesi sürekli uzatılan bir senet gibi geciktirilir". (Adorno, 2009, s. 72). Erich Fromm da, kapitalist sistem ve bu doğrultudaki dünya görüşünün mutsuz bireyleri yarattığının düşüncesindedir. Fromm, bireylerin tüketerek daha çok şeye sahip olarak bir doyum elde edemeyeceği düşüncesindedir ve bu düşünce çerçevesinde yaşayan bireylerin mutsuz bir yaşam sürdüklerinin altını çizmektedir. (Fromm, 1980, s. 14). 
Haz kavramı günümüzde bireylerin yaşantısını sessiz bir şekilde ele geçirmiş bir durumdadır. Tüketim kültürünün hâkim olduğu postmodern dönemin hedonist bireyi anı yaşamaya odaklıdır. Ne yapacağından ziyade ne yapmakta olduğuna önem veren bireyler, sürekli daha fazlasına sahip olma isteği içerisinde koşarak bir yaşam sürmektedir. (Odabaşı, 2014, s. 117). Sıkıntılı durumlardan kendilerini uzak tutarak anı yaşamaya odaklı olan günümüz hedonist bireyinin çalışma hayatında da haz kavramı etkili olmaktadır. Dijitalleşme ile de birlikte bireyler çalışma hayatlarındaki fiziksel sınırlılıkları ortadan kaldırarak iş ortamlarını özgürleştirici bir boyuta taşımaya başlamışlardır.

\section{3.İLETISŞIM TEKNOLOJILERINNDE YAŞANAN GELIŞMELER VE DİJITTALLEŞME}

Bilgi ve iletişim çağının hâkim olduğu günümüz toplumu postmodern dönemin özelliklerini taşımaktadır. Postmodernizm kavramı, mimarlık ve sanat alanlarında yaşanan yenilikleri ifade edebilmek amacıyla ilk olarak 1960'lı yıllarda kullanılmaya başlanmıştır. Postmodernizm kavramı, etkisinin olduğu her alanda farklı düşünürler tarafından farklı şekillerde tanımlandığı için bu kavrama tek bir tanımın yapılabilmesi çok zordur. Baudrillard, Lyotard, Harvey gibi postmodern teorisyenler, iletişim alanında yaşanan teknolojik ilerlemelerin, yeni bilgi biçimlerinin postmodern bir toplumsal oluşum olduğunu düşünmektedir. Baudrillard ve Lyotard ortaya çıkan değişimleri yeni bilgi ve teknoloji biçimleri çerçevesinde incelerken, Jameson ve Harvey, postmodernizmi sermayenin küresel boyutta daha yüksek bir derecede nüfuz sağlaması ve homojenleşmesinin damgasını taşıyan kapitalizmin daha yüksek bir aşamasının gelişimi çerçevesinde değerlendirmiştir. (Doğtaş,2003, s.16).

Postmodern dönem ile birlikte teknolojik alanda büyük gelişmeler yaşanmış ve bu gelişmeler üretim süreçlerini de etkilenmiştir. Üretim süreçlerinde teknolojik gelişmelere bağlı olarak kol gücünün yerine beyin gücü geçmiş ve üretim artık sınırsız bir şekilde yapılmaya başlanmıştır. Teknolojik gelişmelerin yoğun olarak ortaya çıtığ geliştiği bir dönemdir. Modern dönemden postmodern döneme yönelme ile birlikte postmodern dönemin ortaya çıkışı, kapitalist süreç doğrultusunda iki ayrı dönemi temsil eden fordist üretim biçiminden, postfordist üretim biçimine geçiş süreci ile bağlantılıdır. Esneklik kavramı, post-fordizmin en önemli özelliklerinden biridir ve yalnızca üretim alanında değil, bireylerin yaşamları da bu kavram doğrultusunda şekillenmeye başlamıştır. (Odabaşı, 2014, s. 25-27). Esnek üretim modelleri ve teknolojik gelişmelerle birlikte üretim sürecinde öncelik artık bilgi kavramına geçmiştir. Üretim alanında bilgi temel güç olmaya başlamış ve böylece tarım işçilerinin sayısı azalırken, teknik bilgi donanımına sahip beyaz yakalı işçi sayısında artışın olduğu gözlemlenmiştir. (Lyotard, 2000, s.22)

Teknolojik gelişmeler ve esneklik kavramı bireylerin çalışma yaşamlarında değişimler yaratmıştır ve bu değişim ile yeniden şekillenen toplumsal yaşam bazı düşünürler tarafindan gösteri toplumu, tüketim toplumu, sanayi sonrası toplum gibi çeşitli şekilde adlandırılmıştır. Giddens, bu çeşitli adlandırmalara ek olarak, toplumun medya ya da bilgi toplumu olarak nitelendirilmesinin daha uygun olacağ1 üzerinde durmuştur. (Giddens, 2008, s.152). Bauman'ın ise, postmodernizm kavramını geçici olarak kullandığı ve onun yerine akışkan modernite kavramını kullanmaya başladığı gözlemlenmektedir. Bauman'ın bakış açısı doğrultusunda akışkanlık, ilk olarak, davranışlar ve rutinler gibi sosyal formların uzun süre devamlılığını sağlayamamasıdır; ikinci olarak, siyaset ve iktidar bağının birbirinden ayrılmasıdır; üçüncü olarak da bireyselliğin artması, toplumun ağ olarak değerlendirilmesi, uzun soluklu düşünmenin ve planların artık olmayışı, bireylerin daha özgür seçimler doğrultusunda yaşamlarını sürdürebilmeleridir. (Bauman, 2008, s.1-4). Bauman'a göre akışkan modernite ile birlikte toplum içerisinde kurumlar ve bireyler daha esnek ve kararsız olmaya başlamıştır. Akışkan modernite ile Bauman gelişen teknolojik yeniliklere de değinmektedir. İletişim ve ulaşım alanında yaşanan gelişmelere bağlı olarak mekânın ve coğrafi kısıtlamaların ortadan kalması, hız ve zaman kavramlarının önemlerinin artmasına neden olmuştur. (Lyon ve Bauman, 2013, s.46).

Teknolojik gelişmeler ile birlikte bireylerin toplumsal yaşamlarını inceleyen bazı düşünürler teknolojik gelişmelerin bireyleri yalnızlaştırdığı üzerinde durmaktadır. David Harvey, iletişim ve ulaşım alanlarında yaşanan teknolojik gelişmeler sayesinde zaman ve mekân kavramlarının anlamlarını kaybettiğini, iletişim süreçlerinin artık anlık bir şekilde yapılmaya başlandığını ve böylelikle küreselleşmenin önündeki engellerin kalktığının üzerinde durmaktadır. İletişim süreçlerinde yaşanan gelişmelere bağlı olarak bireylerin artık teknoloji ile aracılanmış bir iletişim sürecine girdiklerini belirten Harvey'e göre, bireylerin alışkanlıkları ve yaşantıları da değişmekte ve sanal kültür olarak tanımlanabilecek bir kavram 
ortaya çıkmaktadır. Bireylerin sosyal yaşamlarında yaşanan değişimler Harvey’e göre bireyleri yalnızlığa sürüklemekte ve bireyler zamanla yabancılaşma ve yalnızlaşma sürecine girmektedir. (Harvey, 1999, s.270).

Bauman'a göre ise cep telefonlarının ve sosyal medyanın ortaya çıkması, bireylerin sosyal mesafesi bakımından sorun teşkil etmektedir. Cep telefonlarının ve sosyal medyanın bireylerin toplumsal yaşamına girmesiyle birlikte, toplumsal mekân kavramının tanımı büyük ölçüde değişmiş, mekânlar arası ayırımlar silikleşmeye başlamıştır. (Bauman, 2011, s.40). Akışkan modernite olarak ele aldığ1 günümüz toplumunda bireyler iletişim süreçlerinde artık birbirleriyle olan fiziksel yakınlığın derecesine ve sıklığına bağlı değildirler. (Lyon ve Bauman, 2013, s.46). Bauman'ın bakış açısı doğrultusunda sosyal medya, fiziksel olarak birbirinden uzakta olan bireyleri yakınlaştırmakta fakat birbirleriyle yakın olan bireylerin de birbirlerine uzaklaştı̆̆ının hissine kapılmasına neden olmaktadır. Akışkan modernite içerisinde yaşanan bu teknolojik gelişmeler, bireylerin yüz yüze olan iletişim süreçlerini de silikleştirmeye başlamıştır. (Bauman, 2011, s. 42). Bauman, tuşların ve mesajların hâkim olduğu bu iletişim sürecinde gerçek fiziksel iletişimin önemini kaybetmeye başladığı düşüncesindedir ve bireylerin yüz yüze iletişim kurma becerilerinin gün geçtikçe azalmaya başladığının altını çizmektedir. Kapitalist sistem içerisinde bireylerin kendilerini ifade etmeye sosyalleşmeye vakitlerinin olmadığını belirten Marcuse'ye göre ise, bireyler iletişim ihtiyacını iletişim araçları ile gidermeye başlamıştır. Bu doğrultuda kitle iletişim araçları bireyleri toplumdan kopuk birer robot haline getirmeye başlamıştır. (Büyükyılmaz ve Ofluoğlu, 2008, s. 129).

Günümüzde bireyler gündelik yaşamlarını dijital ortamlar üzerinden var etmeye başlamıştır. Özellikle internet ortamında yaşanan gelişmeler ve bireylerin bu ortamlara erişimin kolaylaşması gerçek yaşamın sanal ortama geçişini hızlandırmaktadır. Web 2.0 ile birlikte etkileşim kavramının sanal ortamlardaki iletişim sürecine eklenmesiyle artık kullanıcılar sadece tüketen değil, üreten konuma da geçmişlerdir ve yeni uygulamalarla internetin içeriğini genişletmeye devam etmektedirler. (Karakulakoğlu, 2015, s.112). Genel anlamı ile bilgisayar dili olarak tanımlanan dijitallik kavramı beraberinde dijital ortamlar kavramını da doğurmuştur. Verilerin üzerine kaydedilip depolandığı ortamların genel adı olarak nitelendirilen dijital ortamlar günümüzde bireylere iletişim alanından çalışma hayatına kadar birçok olanaklar sunmaktadır. İletişim alanında ortaya çıkan teknolojik yenilikler dijitalleşme kavramı ile bir araya gelerek teknolojik yakınsamanın etkisine girmektedir. Yakınsama kavramı iletișim teknolojileri alanında ele alındığı zaman bir araya gelme anlamını taşımakta ve birden çok farklı teknolojilerin birleşerek karma bir teknoloji oluş̧urması manasına gelmektedir. (Öztürk, 2003, s.15). Bunun sonucunda da bireylere akıllı cep telefonlar başta olmak üzere iletişim araçları ile zaman-mekân sınırlarına takılı kalmaksızın çevrim içi olarak televizyon izleme, radyo dinleme, oyun oynama, görüntülü konuşma, toplantı yapma, alışveriş yapma gibi birçok olanaklar sunulmaktadır. Jenkins'e göre, medya araçlarında görülen yakınsama ile birlikte ortaya bir katılımcı kültür çıkmakta ve ortaya çıkan bu katılımcı kültür ile bireyler, dijital ortamlarda daha aktif, sosyal ve göçebe bir yaşam sürmeye başlamaktadır. (aktaran: Kıpçak ve Akın, 2015, s.107). Dijitalleşme ve iletişim teknolojilerinde yaşanan gelişmeler paralel olarak, internet ortamında yaşanan gelişmeler de bireylerin sanal ortamlar üzerinden sürdürebildikleri eylemleri önemli boyutta etkilemektedir.

1970'li yıllarda Arpanet adında kurulan bilgisayar ağı, Birleșik Savunma Bakanlığı'nın desteği ile başlatılmış ve Arpanet olarak kurulan bu ağ, o günlerden günümüze gelişerek günümüzde küresel bir ağa dönüşen internetin ortaya çıkmasını sağlamıştır. (Balevi, 1995, s.16). İnternetin gelişim evreleri incelendiği zaman başlarda etkileşimli iletişim süreçlerinin yer almadığ 1 ve bir broşür şeklinde bilgilerin kullanıcılara tek yönlü bir şekilde aktarıldığı web 1.0 dönemi karşımıza çıkmaktadır. 2004 yılında web 2.0'a geçiş söz konusu olmuştur ve böylece kullanıcılar etkileşim kavramının iletişim sürecine eklenmesiyle birlikte pasif konumdan aktif konuma geçmişlerdir. Temelinde etkileşim kavramını barındıran Web 2.0 ile birlikte "kullanıcının ürettiği içerik" kavramı ortaya çıkmış ve böylelikle kullanıcılar sanal ortamlarda aktif bir role sahip olarak kendi içeriklerini üretmeye başlamışlardır. Kullanıcıların sanal ortamlarda kendi içeriklerini üretmesi demek en genel anlamı ile sanal ortamlarda kendi dünyalarını inşa etmeleridir. Kullanıcıların üreteceği içerikler sosyal paylaşım ağları üzerinden oluşturulan profilden, bloglara yazılan yazılara kadar geniş bir alanı kapsamaktadır. (Varnalı, 2013). 
Web 2.0'ın hâkim olduğu günümüz internet ortamında bilgiye erişim de çok kolay bir hal almıştır. Yaşanan teknolojik gelişmelerle artık bilgi bireylere gelmektedir. Bilişsel yapıları bakımından Web 1.0 kullanıcıları düşünmeye teşvik ederken, Web 2.0 etkileşimsel yapısı ile kullanıcılar arasındaki iletişim süreçlerine dikkat çekmektedir. Web 3.0 birey işbirliğini destekler bir yapısı vardır. Web 2.0 ile Web 3.0 arasındaki etkileşimsel yapı da farklılık göstermektedir. Web 2.0 kullanıcı üzerinde dururken, Web 3.0 kullanıcı işbirliğinin üzerinde durmaktadır. (Karakulakoğlu, 2015, s. 122). Günümüz internetin ve dijitalleşmenin hâkim olduğu bilgi çağıdır. İnternet ortamında yaşanan gelişmelere ve bilgi çağına uyum sağlamak, bireylerin toplum içerisinde yaşamlarını sürdürebilmeleri adına büyük bir öneme sahiptir.

İnternet ortamında Web 2.0 ile etkileşim kavramının süreçlere eklenmesi sonucunda kullanıcılar birbirleri ile çift yönlü bir iletişim sürecine girmiş ve böylece zaman ve mekân sınırlamalarına takılı kalmadan eş zamanlı ya da eş zamansız bir şekilde iletişim halinde olmaya başlamışlardır. Yaşanan gelişmeler sonucunda mekân kavramındaki sınırlılıkların ortadan kalkması ile fiziksel uzaklıklar ortadan kalmış ve dünya üzerinde herkes Marshall McLuhan'ın tanımlaması ile küresel bir köy içerisinde yaşamaya başlamıştır. McLuhan küresel köy kuramı ile iletişim teknolojilerinde yaşanan gelişmelerin bireyleri birleştirdiğini ve bunun sonucunda da dünyanın tek bir bilinçlilik haline dönüşeceğini üzerinde durmaktadır. Günümüzde küresel köyün hâkimi uluslararası firmalardır. Mekân sınırlılığının ortadan kalkması ile birlikte küresel firmalar dünyanın herhangi bir yerinde yaşayan bireylerin tüketim alışkanlıklarından düşünce biçimlerine kadar yaşamlarının her alanında etkili olmaya başlamıştır. "Küresel köy" kavramı, iletişim teknolojilerinde yaşanan gelişmeler sayesinde dünyanın benzer duyuların paylaşıldığı küresel bir köy haline geldiğinin altını çizmektedir. (Rigel ve diğerleri, 2003, s. 18). Küresel köy kavramı bireylerin çalışma yaşamlarında da oldukça etkili olmaktadır. Bireyler artık zaman ve mekân sınırlılıklarından kurtularak kendi alanları içerisinde yarattıkları özgürlükler ile para kazanabilmenin yollarını aramaya başlamış ve internetin bireylere sunduğu olanaklar sayesinde de hem çalışarak hem de özgürlüklerini yaşayabilecekleri alanları "dijital göçebe" olarak yaşamaya başlayarak bulmayı başarmışlardır.

\section{KÜRESEL KÖYÜN KÜRESEL ÇALIŞANLARI: DİJİTAL GÖÇEBELER}

Dijital göçebe kavramı ilk kez 1997 yılında Tsugio Makimoto ve David Manners tarafından yayınlanan bir çalışmada kullanılmıştır. İnternet ve internetin bireylere sunduğu olanakların yeni yeni popülerleşmeye başladığı dönemlerde Tsugio Makimoto ve David Manners "dijital göçebeler" adındaki eserlerini yayınlamışlardır. Makimoto ve Manner, bu dönem ortaya çıkardığ çalışmada internetin bireylerin yaşamlarında ortaya çıkaracağı yenilikleri ele almış ve yeni teknolojilerin özellikle iş ve boş zaman kavramlarında nasıl bir devrimin yapılabileceği üzerinde durmuşlardır. Yazarlara göre artık çalışan bireyler dijital göçebelik kavramı ile ofis ortamına mahkûm olmadan en güzel plajlarda ya da kafelerde kısacası keyif alınabilecek herhangi bir yerde çalışma imkânına sahip olmaya başlamıştır. (Thompson, 2018, s.2). Dijital göçebeler, modern yaşamın koşuşturmasından ve 9-5 çalışma zorunluluğunda bir kaçış olarak ortaya çıkmıştır. (Nash, Jarrahi, Sutherland, Phillips, 2018, s. 2). Dijital göçebeler internet ortamında çalışan işçilerdir. İnternetin ve bilgisayarın olduğu her yer dijital göçebelerin çalışma ortamıdır. İnternetin bireylere zaman ve mekân bağlamında özgürleştirici alanlar sunmasıyla birlikte dijital göçebelerin işlerini yürütmek için fiziksel olarak işyerinde bulunmaları gerekmemektedir ve bu yüzden de çalışırken mekândan bağımsızdırlar. (Thompson, 2018, s.3) Bu hayat tarzı çalışanlarına seyahat olanağı, çalışma saatlerinde esneklik, kabul görmüşs ofis ortamından kaçışı sunmaktadır. (Nash ve diğerleri, 2018, s. 2).

Günümüzde şirketler çalışanlarıyla uzun süreli sözleşmeler yapmak yerine geçici ve kısa dönemli sözleşmeler yapmaya başlamıştır. Kısa süreli iş ekonomisi ya da esnek ekonomi olarak ele alınan gig ekonomi, hem çalışanlarına ve hem de şirketlere esneklik ve özgürlük sunmaktadır. Esnek ekonomi çalışanları mekândan bağımsız bir şekilde kendi çalışma programlarını ayarlayabilmekte, işverenler ise daha az masraf yapmaktadır. Esnek ekonomi ile ortaya çıkan kısa süreli işler tek seferlik işlerdir. Kısa süreli işlerde çalışmak isteyen bireyler bu işi organize eden firmalara üye olan kişilerdir ve websitesi ya da mobil uygulamalar aracılığı ile bu kişilere erişilebilmektedir. İş tamamlandıktan işveren çalışanı performansına göre puanlamakta ve bu da çalışanın bir sonraki işlerine referans olmaktadır. (Thompson, 2018, s.4). Bu durum dijital göçebeler için de geçerlidir. Birbirleriyle iletişim halinde oldukları çevrim içi platformlara üye olan dijital göçebeler, bu platformlar sayesinde kendilerine iş de bulabilmektedirler. 
Keyif alarak çalışan dijital göçebeler için seyahat etmek, değişik yerler görmek ve keyifli vakit geçirmek çalışarak para kazanmaktan önce gelmektedir. Bu yüzden de dijital göçebeler çalışma yerlerini işlerine göre değil, keyif alıp eğlenebilecekleri yerlere göre seçmektedirler.

Dijital göçebeler kavramının tanımlarında genellikle uzaktan çalışanlar, serbest çalışanlar, mekândan bağımsız çalışanlar ve çevrimiçi girişimciler gibi kavramlar kullanmaktadırlar fakat dijital göçebelik bu nitelendirmelerden farklıdır. (Nash ve diğerleri, 2018, s. 2). Bu kavramlar dijital göçebeler topluluğunu sadece bazı açılardan kapsamaktadır ve her biri dijital göçebelerin güncel iş tanımını aktarmakta yersiz kalmaktadır. Dört temel kavramın bir araya gelmesiyle birlikte dijital göçebelerin yaşam tarzı ortaya çıkmaktadır. Bu kavramlar; dijital çalışma, kısa süreli çalışma, göçebe olarak çalışma ve farklı ülkelerde yapılan keyifli seyahatlerdir. (Nash ve diğerleri, 2018, s. 4).

Dijital çalışma: Dijital göçebeler sürekli dünyayı gezerken yaşam tarzlarını korumak için, dijital ortamları kullanarak dijital işlerle ilgilenmektedirler. Son zamanlarda yapılan araştırmalarda bu işler "dijital çalışma" olarak nitelendirilmektedir. Dijital çalışma dijital göçebelerin çalışmalarında kilit rol oynamaktadır. Dijital ortamlar aracılığı ile yapılan işler sayesinde dijital göçebeler mekâna bağımlı kalmadan dünyayı gezerek çalışmalarını sürdürebilmektedir. Bilgisayar başta olmak üzere taşınabilir dijital araçlar mekândan bağımsız bir şekilde seyahat ederek çalışan dijital göçebelere çeşitli kariyer olanakları sunmaktadır. Dijital göçebelerin büyük bir çoğunluğu programcı, yazılım geliştirici, tasarımc1 ya da içerik editörü, blog yazarlığı, grafik tasarımı, çevirmenlik, dijital pazarlama, podcast ve youtube video üretimi hatta finansal ve yönetimsel danışmanlığı gibi alanlarda çalışmaktadır. Bu iş alanlarının yanında, dijital göçebeler için oldukça yaygın olan işler arasında; web sitesi yapımında şirketler ile işbirliği içerisinde olma, onların çevrim içi uygulamalar üzerinden kısa süreli işlerini ve bulut sistemi üzerinden mağaza bilgilerini yürütme ve dijital olarak işverene ürünün son hali hakkında bilgi verme yer almaktadır. Dijital göçebeler birçok teknolojik platformlar kullanarak dijital ortamlardaki işlerini yürütebilmekte ve yeni işler üretebilmektedir. Dijital göçebeler tarafindan kullanılan birçok dijital uygulama ve programlar bulunmaktadır. Bu uygulama ve programlar iki grupta incelenebilir; alana özel olanlar ve genel olanlar. Alana özel olan dijital ortamlar, dijital işlerin alt kategorilerinde yer alan işlere yöneliktir ve uzmanlık gerektirebilmektedir. Örneğin; kod yazan ve paylaşan dijital göçebeler GitHub uygulamasını kullanırken, tasarımcılar ve web sitelerin düzenini yapabilmek için genellikle Adobe Creative Cloud kullanmaktadırlar. Bu programlar genellikle bu alana hâkim bireyler tarafindan kullanılmaktadır. Dijital göçebeler tarafından iletişim kurmak amacı ile kullanılan mesajlaşma uygulamaları da bulunmaktadır. Dijital göçebelerin kullandığı en yaygın mesajlaşma uygulaması Slack'tır. Birbirini tanımayan birçok dijital göçebe bu uygulama ile birbirleriyle iletişime geçebilmektedir. Farklı işleri yapan dijital göçebeler işbirliği içerisinde olduğu kişilerle ya da müşterileri ile toplantı yapabilmekte için de Skype uygulamasını kullanmaktadır. Dijital göçebelerin kullandığı uygulamalar ve programların yanında onlar için temel olan internet bağlantısıdır. Dijital göçebelerin dijital platformlarda çalışıp yaptıkları işleri müşterilerine gönderebilmek için internet bağlantısın olması esastır. Çevrimiçi forumlarda birçok dijital göçebe farklı ülkelerde internete bağlanabilmenin yollarını fiyat, erişebilirlik ve güvenli bağlantı unsurları doğrultusunda tartışmaktadır. Bazıları halka açık mekânlarda bulunan wifi üzerinden internete bağlanmayı tercih ederken diğerleri kendilerine ait olan taşınabilir araçlar ile bağlanmayı tercih etmektedir. (Nash ve diğerleri, 2018, s. 4).

Kısa süreli çalışma: Dijital göçebelerin mesleklerini var edebilmelerinde büyük bir önem taşıyan bir diğer nokta da kısa süreli çalışmaya olan güvenleridir. Kısa süreli çalışma, bireylere istedikleri işlerde bağımsız bir şekilde kısa süreli çalışma imkânı sunmaktadır. İşlerin kısa süreli ve dijital ortamlar üzerinden yapılması bireylere belirli bir mekâna bağlı olmadan, istedikleri yerden dijital ortamları ve teknolojiyi kullanarak çevrim içi bir şekilde serbest işlerde çalışma imkânı sunmaktadır. Kısa süreli işlerde işin gerektirdiği niteliklere ve belirlenen süreye bağlı olarak işin maddi getirisi de değişmektedir. Günümüzde şirketler arasında bu tarz serbest çalışan bireylerle iş yapma eğilimi artmaktadır. Böylelikle şirketler sağlık sigortası ya da işe alım sürecinde ortaya çıkan masraflardan da kurtulmaktadır. Şirketlerde düzenli bir işe sahip olan bireylerin aksine, dijital ortamlarda dijital göçebe olarak kısa süreli işler yapan bireyler düzenli bir gelir için sürekli iş aramak zorundadırlar. Birçok dijital göçebe dijital ortamlarda kendi reklamlarını yaparak iş bulmaktadır. Bazıları kendilerine yönelik reklam yapıp firmalara mail yoluyla ulaştırırken, bazıları da LinkedIn ve Medium, Upwork ve Remoteok gibi ağları kullanarak kendi farkındalıklarını arttırmaktadır. (Nash ve diğerleri, 2018, s. 5). 
Göçebe olarak çalışma: Dijital göçebe yaşam tarzının belki de en göze çarpan yönü, yalnızca ülkeden ülkeye değil, çalışma alanından çalışma alanına da sürekli bir hareketin olmasıdır. Birçok dijital göçebe, benimsedikleri yaşam tarzı ile rutin hayatın dışına çıkarak iş alanında bir özgürlük elde etmeye başlamıştır. (Nash ve diğerleri, 2018, s. 6). İşlerini evden yürütenler genellikle belirli bir yerde ya da ev içerisinde çalışmaktadırlar. Dijital göçebeler ise, mekândan bağımsız çalışma durumunu daha da ileriye götürerek hem yurt içinde hem de yurt dışında seyahat ederek çalışmalarını sürdürmektedirler. Çalışacakları yeri işe göre değil, eğlence ve yaşam tarzı beklentilerine göre seçmektedirler. Bu nedenle, genellikle oldukça uygun fiyatlı ve hoş karşılanabilecekleri konforlu, sıcak, doğal yerleri tercih etmektedirler. (Thompson, 2018, s.3). Dijital göçebeler ile evden çalışanlar yaşam tarzları bakımından farlılık göstermektedir. İşlerini evden yürütenler genellikle ev ve işi dengede tutmaya çalışırken, dijital göçebeler boş zaman ve işi nadiren de çocuk yetiştirme ve işi dengede tutmaya çalışmaktadır. (Thompson, 2018, s.4).

Farklı ülkelerde yapılan keyifli seyahatler: Dijital göçebeler durmaksızın eş zamanlı olarak hem gezip hem çalıştıkları için yaşantılarında iş ve yaşam birbirine geçmiş bir şekildedir. Dijital göçebeler, göçebe şekilde çalışan bireylerden birçok yönü ile farklılaşmaktadır çünkü dijital göçebeler aynı zamanda tüm dünyayı durmaksızın büyük bir tutku ile keşfederek gezen bireyleridir. Dijital göçebeler seyahat etmek için öncelikli olarak Chiang Mai, Ubud ve Phuket gibi egzotik yerleri tercih etmektedir. Bu yerlerin başta gelmesinin en temel sebebi keyif alınabilecek egzotik yerler olmasının yanında yaşam şartlarının makul ve internete sorunsuz bir şekilde erişimin olmasıdır. Dijital göçebeler kendi yaşam tarzını seçebilen bireyler olduğu için birçoğu surf, dağcılık, kayak gibi hobilerin yapılabileceği tropikal yerleri tercih etmektedirler. Bazı dijital göçebeler kışlarını tropik bölgelerde geçirip yaz aylarında kuzey Avrupa'yı tercih etmektedirler. Dijital göçebelerin dünyayı gezebilmeleri için Hacker Paradise, Digital Nomad Conference gibi seyahat edecekleri bölgeler hakkında birbirleri ile haberleştikleri programlar vardır. Bazı dijital göçebeler kendilerine seyahat arkadaşı bularak konaklama ve yolculuk masraflarını en aza indirmeyi tercih etmektedir.

Dijital göçebeler, Facebook sayfaları aracıllı̆ı ile kendilerine konaklama ayarlamakta, NomadList ve Slack uygulamaları ile birbirleri ile iletişime geçebilmektedir. Forumlar üzerinden dijital göçebeler birbirlerine güzergâhlar, internet bağlantısının güçlülügü̈, yaşam şartları ve eğlenebilecekleri ortamlar ve aktiviteler hakkında önerilerde bulunmaktadır. Örnek olarak bir NomadList üyesi airbnb üzerinden nasıl uzun süreli ve ucuz konaklama ayarlanabileceği konusunda paylaşımlar yapmaktadır (Nash ve diğerleri, 2018, s. 6) Dijital göçebeler konaklamalarını genellikle paylaşım ekonomisinin örneklerinden olan airbnb.com üzerinden yapmaktadırlar. (Thompson, 2018, s.5) Turistlerin aksine dijital göçebeler seyahat ederken çalışmak zorundadırlar bu yüzden seyahatlerini ve çalışmalarını dengede tutmaları gerekmektedir.

Dijital göçebeler kavramının tam anlamı ile anlamlandırılabilmesi için bu dört temel kavram bireylerin yaşantılarında yer alması gerekmektedir. Dijital göçebelik bu dört temel kavramın kesiştiği noktada ortaya çıkmaktadır.

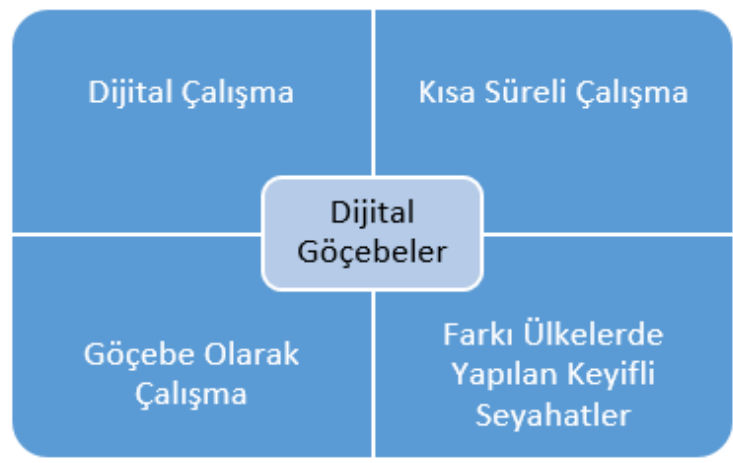

Şekil-1: Dijital Göçebeler Kavramını Oluşturan Temel Kavramlar (URL,1)

Dijital göçebeler zamanlarını kendileri için uygun olan ülkelerde geçirme özgürlüğüne sahip olsalar da, tam zamanlı bir iş güvencesinin olmamasından kaynaklı maddi sıkıntıların ortaya çıkma riski söz konusudur. Dijital göçebe olarak çalışan bireyler dijital işlere ve kısa süreli işlerin devamlılığına 
güvenmektedir. Yine de olası kriz ve sorunlara karşı kısa süreli işlere güvenerek uzun süreli işlerde çalışmamak onlar için bir risk teşkil etmektedir. (Thompson, 2018, s, 5). Bu duruma ek olarak, dijital göçebeler seyahat edip keyifli anlar geçirdikleri zaman dilimi ile çalışma zamanını dikkatli bir şekilde dengede tutmak zorundadırlar. Dijital göçebelerin yaşamlarında iç içe geçmiş olan bu iki zaman diliminin yönetimi belirledikleri yaşam standardının devamlılı̆̆ için önem teşkil etmektedir.

Ülkemizde de dijital göçebelerin sayısı azımsanmayacak kadar fazladır. İstanbul, Bursa, Ankara, İzmir, Bodrum, Antalya, Alanya, Konya, Adana ve Gaziantep dijital göçebelerin ülkemizde tercih ettikleri yerlerdir. (Nomadlist, 2019)

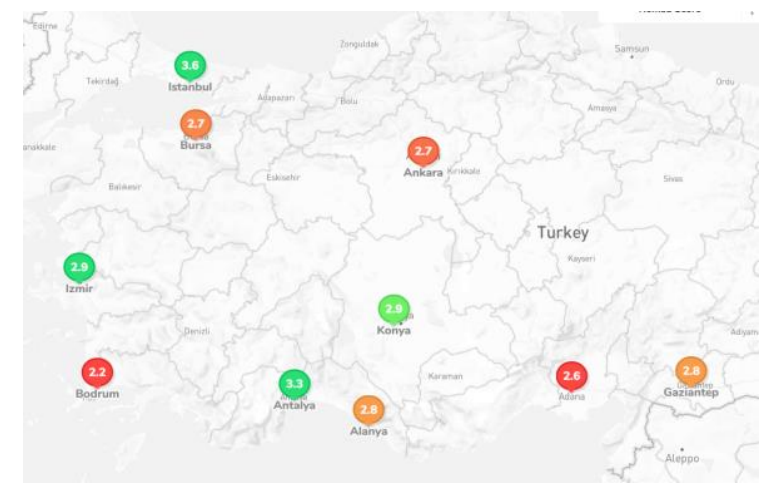

Şekil-2: Dijital Göçebelerin Türkiye'de Tercih Ettikleri İller (URL,2)

Dijital göçebeler gidecekleri yerleri keyifli ve internete erişimin sorunsuz olabileceği bir yer olmasının dışında belirli unsurlara göre tercih edip puanlamaktadır. Dijital göçebeler seyahat edecekleri yerleri tercih ederken öncelikli olarak düşük maliyetli yaşam şartına, sorunsuz internet bağlantısına ve gidecekleri yerlerde yabancılara karşı misafirperver olunmasına dikkat etmektedirler. Bu kriterleri en iyi karşılayan ve dijital göçebeler tarafindan en çok tercih edilen yer, Bali Canggu'dur. (Dodd, 2018, s.7). Dijital göçebeler gittikleri yerleri puanlayarak ve yorum yaparak diğerlerine yol göstermekte ve birbirlerinin tercihlerinde etkili olmaktadır. Çalışma hayatı, dijitalleşme ve haz odaklı bir yaşam ile birlikte yeniden şekil almaktadır. Dijital göçebeler, çalışma ortamlarını dört duvar arasından keyif alabilecekleri yerlere taşımakta ama bunu yaparken de ölçülü bir yaşam sürmeye de dikkat etmektedirler.

\section{SONUÇ}

Postmodern dönem ile birlikte yaşanan teknolojik gelişmeler ve dijitalleşme, haz odaklı yaşayan bireylerin çalışma ortamlarına esneklik kavramı ile birlikte özgürlük alanları yaratarak rutin olanın dışına çıkmalarını sağlamaktadır. İletişim süreçlerinde yaşanan teknolojik gelişmeler, zaman ve mekân sınırlılıklarını ortadan kaldırarak küresel bir köyün ortaya çıkmasını sağladığı gibi, çalışma ortamlarındaki fiziksel sınırlılıkları da ortadan kaldırarak küresel köyün küresel işçileri olarak karşımıza çıkan dijital göçebelerin de ortaya çıkmasını sağlamıştır. Sürekli yeni olana ulaşmaya çalışarak mutluluğu arayan ve anı yaşamaya önem veren hedonist bireyler artık çalışma hayatlarında da geçici ve kısa süreli işlerde çalışarak hem anı keyifli bir şekilde yaşamakta hem de çalışma hayatlarına devam edebilmektedirler. Postmodernizm ile birlikte toplumda daha da belirgin hale gelen bireyselleşme, dijital göçebeler kavramında da kendisini göstermektedir. Dijital göçebelik kavramı ile bireyler, ofis ortamından bireysel çalışma yaşamına geçmeyi tercih etmektedir.

Çalışma eylemi geçmişten günümüze yaşamsal faaliyetlerin sürdürülebilmesi için en temel eylemlerden biri olmuştur. İlkel dönemden günümüze insanoğlu dünyaya geldiği andan itibaren hayatta kalmanın savaşını vermeye başlamış ve temel gereksinimlerini giderebilmek için sürekli bir çalışma temposunun içerisine yaşamına devam etmiştir. Zaman içerisinde üretim ve tüketim süreçlerinde yaşanan gelişmeler ve değişmeler bireyleri çalışma ortamlarına daha da mahkûm etmeye başlamıştır. Dijital çağ ile birlikte bireyler günümüz toplumun kargaşasından uzaklaşabilmek adına internet ortamında vakit geçirerek, gerçek hayattan bir kaçış sürecine girmeye başlamıştır. Yaşanan bu yeniliklerin bireylerin çalışma alanına da yansımasıyla birlikte, bireylerin çalışma yaşamları mekândan ve zamandan bağımsız olmaya başlamıştır. Bireyler, dijital ortamlarda onlara sunulan bu esnek yaşamı ve yenilikleri anı yaşama 
güdüleriyle birleştirip hem gezip hem çalışmaya başlayınca bu durum bireylerin çalışma yaşamlarına özgürleştirici bir boyut kazandırmaya başlamıştır. Dijital göçebelik kavramı ile çalışma hayatına göre şekillenen yaşamların merkezine keyif alınabilecek anlar geçmiş ve bireyler yaşam alanlarını işlerine göre değil, eğlenebilip keyif alabilecekleri yerlere göre belirlemeye başlamıştır.

Sonuç olarak, Aristippos'un hedonizm düşüncesi bağlamında gelecek kaygısı çekmeyen, anın kıymetini bilerek, neşesini kaybetmeden ölçülü bir şekilde yaşayan günümüz hedonist bireyleri dijitalleşmenin getirdikleri ile birlikte bu yaşam felsefesini çalışma hayatları ile birleştirme şansına sahip olmaya başlamıştır. Hayatta kalabilmek için çalışıp para kazanan bireyler, dijital göçebelik kavramı ile anı yaşamak ve keyif almak için çalışan bireylere dönüşmeye başlamıştır. Sürekli çalışarak daha çok para kazanma güdüsünü bir tarafa bırakıp, ölçülü ama haz alarak yaşamayı tercih eden dijital göçebelerin sayıları, iş alanları ve çalışma ortamları teknolojik gelişmelere bağlı olarak gün geçtikçe daha da artacaktır.

Bilgilendirme / Acknowledgement: Bu makale, 18-19 Haziran 2019 tarihlerinde İstanbul'da gerçekleştirilen 2. Uluslararası Eğitim ve Sosyal Bilimlerde Yeni Ufuklar (ICES-2019) adlı kongrede sözlü bildiri olarak sunulmuştur.

\section{KAYNAKÇA}

Adorno, T. (2009). Kültür endüstrisi. (çev. Nihat Ülner). İstanbul: İletişim Yayınları.

Akarsu, B. (1998). Mutluluk ahlakl: Ahlak öğretileri-I. İstanbul: İnk1lap Yayınevi.

Aster, V.E. (2005). Illkçağ ve ortaçağ felsefe tarihi. (çev. Vural Okur). İstanbul: Düşüncebilim Yayınları.

Bahtinur M. (2015). Modern dünyada mutluluk: John Stuart Mill’in faydac1 etiği. Atatürk Üniversitesi, Sosyal Bilimler Enstitüsü Dergisi, 19(1), 23-30.

Balevi, E. (1995). Internet: Siber uzay sörfçüsünün seyahat rehberi. Ankara: Seçkin Yayınevi.

Bauman Z. (2008). Liquid times living in an age of uncertainty. UK: Polity Press.

Bauman, Z. (2011). Akışkan modern dünyadan 44 mektup. (çev. Pelin Siral). İstanbul: Habitus Kitap. 
Bauman, Z. (2011). Yaşam sanatı. (çev. Akın Sarı). İstanbul: Versus Kitap.

Dodd, C. (2018). The digital nomad's guide to the world 2018: 14 destinations. in-depth profiles. Create Space Independent Publishing Platform.

Doğtaş, D. (2003). Postmodernizm ve eleştirisi: Tartışmalar/uygulamalar. İstanbul: Anka Basım.

Epiküros. (2014). Özdeyişler mektuplar ve aforizmalar. (çev. Genim Renas). İstanbul: Arya Yayınc1lık.

Fromm, E. (1980). Freud düşüncesinin büyüklü̆̈̈u ve sınırları. (çev. Aydın Arıtan). İstanbul: Arıtan Yayınlar1.

Fromm, E. (1994). Erdem ve mutluluk: Ahlak psikolojisi üzerine bir inceleme. (çev. Ayda Yörükan). İstanbul: Türkiye İş Bankası Yayınları.

Giddens, A. (2008). Sosyoloji. İstanbul: Kırmızı Yayınları.

Jay, M. (2006). Diyalektik imgelem. (çev. Ünsal Oskay). İstanbul: Belge Yayınları.

Hancerlioğlu, O. (2000). Düşünce tarihi. İstanbul: Remzi Kitabevi.

Harvey, D. (1999). Postmodernliğin durumu. (çev.Sungur Savran). İstanbul: Metis Yayınları.

Karakulakoğlu, E.S. (2015). Geleceğin Web teknolojileri: Web 3.0 ve etkileşim. (der. Özlem Oğuzhan). İstanbul: Kalkedon Yayınc1lık.

Kıpçak, S., Akın, C. (2015). Savaşın dijital duvarlarda temsili: Gazze ve Bansky örneği. Çanakkale Onsekiz Mart Üniversitesi, Uluslararası Yeni Medya ve Yeni Yaklaşımlar Konferansı, Yeni Medyada Barışv ve Savaş Dili, 101-113.

Lyon, D., Bauman, Z. (2013). Akışkan gözetim. (çev. ElçinYılmaz). İstanbul: Ayrıntı Yayınları.

Lyotard, J. F. (2000). Postmodern durum, bilgi üzerine bir rapor. (çev. Ahmet Çiğdem). Ankara: Vadi Yayınları.

Nash, C., Jarrahi, M.H., Sutherland, W., Phillips, G. (2018). Digital nomads beyond the buzzword: Defining digital nomadic work and use of digital Technologies. Lecture Notes in Computer $\begin{array}{lllll}\text { Science. } & 1 & \text { Mayis } & 2019 & \text { tarihinde }\end{array}$ https://www.researchgate.net/publication/322923942_Digital_nomads_beyond_the_buzzword_De fining digital nomadic work and use of digital technologies adresinden erişildi.

Nomadlist. 22 Haziran 2019 tarihinde https://nomadlist.com/turkey/map adresinden erişildi.

Odabaş1, Y. (2014). Postmodern pazarlama. İstanbul: MediaCat.

Ofluoğlu, G., Büyükyılmaz, O. (2008). Yabancılaşmanın teorik gelişimi ve tarihsel süreç içinde farklı alanlarda görünümleri. $\quad$ Kamu-iş; $\quad 10,(1), \quad 113-144$. 22 Haziran 2019 tarihinde http://www.kamu-is.org.tr/pdf/1015.pdf adresinden erişildi.

Öztürk M. C. (2003). Dijital iletişim ve yeni medya. Eskişehir: Anadolu Üniversitesi Yayınları.

Rigel, N. Batuş, G. Yücedoğan, G., Çoban, B. (ed.). (2003). Kadife karanlık- 21. yüzyıl iletişim çağını aydinlatan kuramcllar. İstanbul: Su Yayınevi.

Thompson, B. Y. (2018). Digital nomads: Employment in the online gig economy. Glocalism: Journal of Culture, Politics and Innovation, 1-26. DOI: 10.12893/gjcpi.2018.1.11

Thompson, B. Y. (2018). The digital nomad lifestyle: (Remote) Work/Leisure balance, privilege, and constructed community. International Journal of the Sociology of Leisure, 3(2), 27-42.

Tolan, B. (1981). Çağdaş toplumun bunalımı anomi ve yabancılaşma. Ankara: İktisadi ve Ticari Bilimler Akademisi Yayınları.

Varnalı, K. (2013, 20 Ağustos). Sosyal medyada üretilen, paylaşılan ve tüketilen içerik üzerine, digitalage. 1 Mayıs 2019 tarihinde http://www.digitalage.com.tr/makale/sosyal-medyada-uretilenpaylasilan-ve-tuketilen-icerik-uzerine/ adresinden erişildi. 
Vernon, M. (2010). Mutluluk için felsefe. (çev. Elçin Karadoğan). İstanbul: Sel Yayıncılık.

\section{GÖRSEL KAYNAKÇA}

URL 1: Nash, C., Jarrahi, M.H., Sutherland, W., Phillips, G. (2018). Digital nomads beyond the buzzword: Defining digital nomadic work and use of digital Technologies, Lecture Notes in

$\begin{array}{lllll}\text { Computer } & \text { Science. } & 1 & \text { Mays } & 2019\end{array}$

https://www.researchgate.net/publication/322923942_Digital_nomads_beyond_the_buzzword_De fining_digital_nomadic_work_and_use_of_digital_technologies adresinden erişildi.

URL 2: 5 Haziran 2019 tarihinde https://nomadlist.com/turkey/map adresinden erişildi. 